\title{
Anti-Uterine Fibroid Effect of Standardized Labisia Pumila Var. Alata Extracts In Vitro and in Human Uterine Fibroid Cancer Xenograft Model
}

\author{
Norfahana Zakaria ${ }^{1}$, Khamsah Suryati Mohd ${ }^{1 *}$, Mohammed Ali Ahmed Saeed ${ }^{2}$, \\ Loiy Elsir Ahmed Hassan ${ }^{3}$, Armaghan Shafaei², Fouad Saleih R. Al-Suede ${ }^{4}$, Abdul \\ Hakeem Memon $^{5}$, Zhari Ismail ${ }^{2}$
}

\begin{abstract}
Background: Uterine fibroids are a common type of solid tumor presenting in women of reproductive age. There are very few alternative treatment available from conventional treatment involving surgeries. Labisia pumila var. alata or locally known as 'Kacip Fatimah' was widely used as traditional medicine in Malaysia. This plant has been used to maintain a healthy female reproductive system. The present study aimed to evaluate anti fibroid potential of $L$. pumila extracts through in vitro apoptosis activity against uterine leiomyoma cells (SK-UT-1) and in uterine leiomyoma xenograft model. Evaluation of bioactive markers content were also carried out. Methods: Apoptotic induction of the extracts was determined by morphological examination of AO/PI dual staining assay by flourescent microscopy and flow cytometry analysis on Annexin V-FITC/PI stained cells. In vivo study was done in immune-compromised mouse xenograft model. HPLC analysis was employed to quantify marker compounds. Results: Morphological analysis showed L. pumila induced apoptosis in a dose dependent manner against SK-UT-1 cells. In vivo study indicated that L. pumila significantly suppressed the growth of uterine fibroid tumor. All tested extracts contain bioactive marker of gallic acid and cafeic acid. Conclusion: This work provide significant data of the potential of L. pumila in management of uterine fibroids.
\end{abstract}

Keywords: SK-UT-1- Labisia pumila- uterine fibroid- uterine leiomyoma xenograft

Asian Pac J Cancer Prev, 21 (4), 943-951

\section{Introduction}

Uterine fibroids, or leiomyomas, are the most common type of solid tumor presenting in women of reproductive age, with an incidence of 20-25\% (Buttram and Reiter, 1981). Although they may be asymptomatic, fibroids often cause a variety of health problems for women, including menorrhagia, chronic pelvic pain, pressure symptoms on adjacent pelvic organ, recurrent miscarriages, obstructed labour, postpartum haemorrhage and sepsis (Stewart, 2001). As a result of these problems, uterine fibroid is the most common indication for hysterectomy in Australia and USA (Farquhar and Steiner, 2002). In addition to these concern, women are increasingly searching for alternative treatments rather than hysterectomy for fibroid disease. Accumulating evidences indicate that high intake of green vegetables and fruit seem to have a protective role and associated with reduced risk of uterine fibroids of US and Italian populations (Vidya and Nagini, 2012; Surh,
2003). This result supports the possible use of dietary phytochemicals for the prevention and treatment of uterine fibroids. However, phytochemical based research in uterine fibroids is at its infancy. Epigallocatechin gallate (EGCG), an extract of green tea showed an ability to inhibit the proliferation of human leiomyoma (HuLM) cells and induces apoptosis (Zhang et al., 2010). Malik et al. (2009) found that curcumin has an antiproliferative effect on leiomyoma cells via regulation of apoptosis pathway and inhibited production of the extracellular matrix (ECM) component fibronectin.

Labisia pumila or locally known as Kacip Fatimah is a well known herb among Malaysian which has received much attention since more than a decade ago. There are three known varieties of L. pumila which are L. pumila var pumila, L. pumila var. alata and $L$. pumila var. lanceolata (Stone, 1988). Till now, it is consumed by local people to maintain a healthy female reproductive system, treating menstrual irregularities,

${ }^{1}$ Faculty of Bioresources and Food Industry, Universiti Sultan Zainal Abidin, Besut Campus, Besut, Terengganu, ${ }^{2}$ Department of Pharmaceutical Chemistry, School of Pharmaceutical Sciences, ${ }^{4}$ Eman Biodiscoveries Sdn. Bhd., Suite 126, Level 1, EUREKA Complex, Universiti Sains Malaysia, Minden, Penang, Malaysia, ${ }^{3}$ Department of Botany, Faculty of Science and Technology, Omdurman Islamic University Omdurman, Sudan, ${ }^{5}$ Department of Pharmacognosy, Faculty of Pharmacy, University of Sindh, Jamshoro, Pakistan.*For Correspondence: khamsahsuryati@unisza.edu.my 
as well as enhancing sexual function. Plants from the Myrsinaceae family were known to exhibit a number of interesting pharmacological properties such as antiinflammatory, antiviral, anti-tumor (Kobayashi and De Meji'a, 2005), cytotoxic (Chang et al., 2009), antibacterial (Karimi et al., 2011), anti-inflammatory (Ibrahim et al., 1996; Rasadah et al., 2001) and antioxidant (Mohamad et al., 2009) properties. Recently, numerous scientific researches on L. pumila were conducted. Study on anticancer potential of $L$. pumila in vitro models revealed its ability to inhibit HM3KO cell growth by arrested cell cycle at G1 phase and induce apoptosis via up and down regulation of $\mathrm{Bax} / \mathrm{Bcl}-2$ protein, mediated through a $\mathrm{p} 53$ dependent pathway (Azimahtol et al., 2012). Melissa et al. (2013) suggests that high estrogenic activity and lower cell proliferation of L. pumila water extract on human endomentrial cell line provides a good insight for its use as an estrogen replacement agent. Manneras et al., (2010) showed that L. pumila exhibited estrogenic effect and improves insulin sensitivity and lipid profile in PCOS (polysystic ovary syndrome) rats without affecting body composition. Preliminary research by Ghafar et al., (2013) showed a possible anti-angiogenic effect of L. pumila extracts. Nadia et al., (2012) found that the phytoestrogenic, anti-inflammatory, and antioxidative properties that make L. pumila as an effective agent against osteoporosis.

Various diseases have been treated using L. pumila and most focused on treating and maintaining women health related problem including postpartum care, improve menstrual cycle, treat delayed fertility, improve body strength after delivery, contract the birth channel, reduce menopausal symptoms, alleviating fatigue, promoting emotional well-being, relieving constipation, acting as anti-flatulence and anti-dysmenorrheal (Burkill, 1966; Zakaria and Mustafa, 2010). Based on its pharmacological properties and practices in traditional management, this plant possesses a potential to be develop for a new treatment in curing uterine fibroid disorder. At present, there is a lack of effective treatment for uterine fibroids. (Walker and Stewart, 2005; Lethaby et al., 2002; Sankaran and Mayonda, 2008). Thus, the present study provide a basis for using L. pumila in the management of uterine fibroids in women. Furthermore, there was none report on the use of L. pumila in treating uterine fibroid. Hence, we aim to evaluate the potential effect of this plant on the induction of apoptosis in uterine leiomyosarcoma cell lines and evaluation of L. pumila nano-formulation in order to improve the bioavailability of the active constituents and eventually provide some additional data and information for the future use.

\section{Materials and Methods}

\section{Preparation of standardized plant materials}

The whole plant of L. pumila were puchased from HERBAGUS Sdn Bhd. A voucher specimen (No 11607) was deposited at the herbarium of School of Biological Sciences, Universiti Sains Malaysia. The plant was pulverized into fine powder using electric grinder (Retsch, Germany). Two hundred grams of powdered plant was extracted with 50\% ethanol (LPEW) using soxhlet extraction technique and $100 \%$ water (LPW) using maceration technique, respectively.

\section{Preparation of liposome of L. pumila}

Liposome of L. pumila (LPF), a formulated extract of $L$. pumila was prepared as described by Aisha et al., (2014). Briefly, L. pumila extract was dissolved in ethanol while soybean phospholipids was dissolved in chloroform, the solutions were mixed, and then solvent was evaporated under vacuum using rotary evaporator at $45^{\circ} \mathrm{C}$ and further dried in the oven at $60^{\circ} \mathrm{C}$ for $1 \mathrm{~h}$.

Qualitative and quantitative of biomarker by High Performance Liquid Chromatography (HPLC)

HPLC analysis was carried out based on the method proposed by Saeed (2018). Briefly, the experiment was performed using an Agilent Technologies 1260 Infinity HPLC system (Agilent, USA) equipped with autosampler, quertenary pump, degasser, column oven an UV detector. Separation was performed using a reverse phase C-18 Eclipse column $(250 \times 4.6 \mathrm{~mm}, 5 \mu \mathrm{m})$. The column temperature was set at $35{ }^{\circ} \mathrm{C}$, using gradient mobile phase consists of $0.2 \%$ aqueous acetic acid denoted as $\mathrm{A}$ and acetonitrile denoted as B. Initial run conditions were $80 \% \mathrm{~A} ; 20 \%$ B for $5 \mathrm{~min}$. After that between 5.1 to $20 \mathrm{~min}$ there was linear increase of solvent B up to $90 \%$. Between 20.1 to $30 \mathrm{~min}$ there was a linear decrease of starting run conditions $(80 \% \mathrm{~A} ; 20 \% \mathrm{~B})$. The elution program was set as gradient for 30 minutes with flow rate was maintained at $1 \mathrm{~mL} / \mathrm{min}$ and the injection volume was $10 \mu \mathrm{L}$. The chromatogram was collected under 270 $\mathrm{nm}$ and data acquisition was carried out using Agilent ChemStation software.

Briefly, a stock solution of gallic acid and caffeic acid mixture were prepared at $1 \mathrm{mg} / \mathrm{mL}$ in methanol (HPLC grade) and serial diluted to obtain $0.49-250 \mu \mathrm{g} / \mathrm{mL}$. L. pumila (100\% water and $50 \%$ ethanol water) extracts were prepared at $10 \mathrm{mg} / \mathrm{mL}$ in their respective solvents and further diluted to $5 \mathrm{mg} / \mathrm{mL}$. All solutions were filtered through $0.45 \mu \mathrm{m}$ syringe filters prior to analysis. L. pumila extracts $(10 \mu \mathrm{L})$ were injected at $5000 \mu \mathrm{g} / \mathrm{mL}$ and the peak area corresponding to markers were recorded. The linear regression equations of the standard calibration curves were applied in order to calculate the concentration of the reference markers in the samples, and the results were presented as average $\% \mathrm{wt} / \mathrm{wt}$ using formula:

$\% \mathrm{wt} / \mathrm{wt}=($ the found concentration $\div 5,000 \mu \mathrm{g} / \mathrm{mL})$ $\mathrm{x} 100,(\mathrm{n}=3)$.

Gallic acid (GA) and caffeic acid (CA) were used as an identification reference markers for L. pumila plant as stated in Malaysian herbal monograph Vol 1 (Zhari et al., 1999). In addition, GA and CA are the phenolic acid that abundantly found in L. pumila extract (Karimi et al., 2011; Chua et al., 2011).

\section{Cell lines and culture condition}

Uterine leiomyosarcoma SK-UT-1 cells and normal A7r5 smooth muscle were purchased from American Type 
Cell Culture Collection (ATCC), USA (ATCC No. HTB 1114 and ATCC No. CRL 1444). These cells were cultured in RPMI-1640 supplemented with 10\% fetal bovine serum and $1 \%$ penicillin-streptomycin. Cells were maintained in a humidified incubator at $37^{\circ} \mathrm{C}$ with $5 \% \mathrm{CO}_{2}$ and grown in $75 \mathrm{~cm}^{2}$ culture flask supplied with $12 \mathrm{~mL} \mathrm{DMEM}$, and after a few passages cell were seeded in 96-well plate and 6-well plate. All studies were carried out with cells at $70-80 \%$ confluency.

Cell death analysis by Acridine Orange and Propidium Iodide (AO/PI) double staining and fluorescence microscopy

Acridine Orange and Propidium Iodide double staining assay (AO/PI) was used to study the mode of cell death by following the method of Tajudin et al., (2012) with slight modifications. We have previously reported the cytoxicity activity of marker compounds and extracts with the following $\mathrm{IC}_{50}$ values; Gallic acid: $4 \mu \mathrm{g} / \mathrm{mL}$, Cafeic acid: $8 \mu \mathrm{g} / \mathrm{mL}$, EGCG: $22 \mu \mathrm{g} / \mathrm{mL}$, LPEW: $22 \mu \mathrm{g} / \mathrm{mL}$, LPW: $28 \mu \mathrm{g} / \mathrm{mL}$ and LPF: $32 \mu \mathrm{g} / \mathrm{mL}$ (Zakaria et al., 2019). In this study, SK-UT-1 cells were treated with the extracts and its biomarker for 24 hours according to their $\mathrm{IC}_{50}$, values and extra dosages of $100 \mu \mathrm{g} / \mathrm{mL}$ and $250 \mu \mathrm{g} / \mathrm{mL}$ for $72 \mathrm{~h}$. Cells without treatment were used as a negative control. Each of the treatments was done in triplicate. After incubation, cells were harvested and pellet down at $100 \mathrm{~g}$ for $10 \mathrm{~min}$. Cell pellets were washed with PBS by centrifuging the cells as mention above. Then, pellets were suspended in $50 \mu \mathrm{L}$ of acridine orange solution (10 $\mu \mathrm{g} / \mathrm{mL})$ and $50 \mu \mathrm{L}$ of propidium iodide solution $(10 \mu \mathrm{g} /$ $\mathrm{mL}$ ) for $5 \mathrm{~min}$. A volume of $10 \mu \mathrm{L}$ of stained cells was added into glass slide and covered with a cover slip. Viable, apoptotic and necrotic cells were observed using the fluorescence microscope.

\section{Cell death analysis by Annexin V/PI double staining and flow cytometry}

The proportion of apoptotic cells was done using FITC Annexin V Apoptosis detection kit I (BD Pharmingen ${ }^{\mathrm{TM}}$, USA) according to manufacturer instruction. Briefly, cells were seeded $\left(1 \times 10^{5}\right)$ into 6 -well plate with $2 \mathrm{~mL} \mathrm{DMEM}$ and cultured overnight at $37^{\circ} \mathrm{C}$. Cells were then treated the same manner as previous for $24 \mathrm{~h}$, subsequently harvested by removing old media and washed twice with cold PBS. Cells were then re-suspended in $1 \mathrm{~mL}$ of $1 \mathrm{X}$ binding buffer $\left(1 \times 10^{6}\right.$ cells $\left./ \mathrm{mL}\right)$ and centrifuged at $300 \mathrm{xg}, 4^{\circ} \mathrm{C}$ for $10 \mathrm{~min}$. A volume of $100 \mu \mathrm{L}$ of $1 \times 10^{6}$ cells $/ \mathrm{mL}$ was transferred to a $5 \mathrm{~mL}$ flow-cyto tube. Then a volume of $5 \mu \mathrm{L}$ of Annexin V-FITC and $5 \mu \mathrm{L}$ of propidium iodide (PI) was added and incubated for 15 minutes at room temperature in the dark. A volume of $400 \mu \mathrm{L}$ of $1 \mathrm{X}$ binding buffer was added and cells were analysed by flow cytometer using CytoFLEX flow cytometry with CytExpert software version 1.1 (Beckman Coulter, USA). About 10,000 events were sorted accordingly into viable, early apoptotic, late apoptotic and necrotic cells. The percentage of each category of apoptosis and cell death were determined.
In vivo uterine fibroid xenograft in athymic mouse model

The present work was approved by the USM Animal Ethical Committee (Reference Number USM / Animal Ethics Approval / 2016 / (101) (818). SK-UT-1 cells were cultured in RPMI 1640 cell culture medium supplemented with 10\% Foetal Bovine Serum and 1\% penicillin/streptomycin. The cells were collected by trypsinization when reached $70 \%$ confluences. After that the cells ( $200 \mu \mathrm{L}$ containing $5 \times 10^{6}$ cells $)$ were implanted subcutaneous into the right flank of the nude mice (4-6 weeks old, 22-24 g) using $1 \mathrm{~mL}$ syringe attached to 25 Gauge needle (Al-Suede et al., 2014). The mice were maintained in a specific pathogen germ-free environment. Twenty four mice randomly divided into four groups of six mice each. Treatment was started when tumor size reached $>100 \mathrm{~mm}^{3}$ (Ahamed et al., 2012). The animals were divided into four groups. Group I and II were received oral treatment with 200 and $400 \mathrm{mg} / \mathrm{kg}$ body weight of LPF, respectively. Group III was given $0.1 \mathrm{~mL}$ autoclaved distilled water (negative control) and group IV received suramin (positive control). It is noted that the toxicity study has been conducted on the plant extract and showed no mortality up to $2,000 \mathrm{mg} / \mathrm{kg}$ (Saeed, 2018). Based on that, 200 and $400 \mathrm{mg} / \mathrm{kg}$ have been selected by dividing the LD50 ie $2,000 \mathrm{mg} / \mathrm{kg}$ with 10 and 5 . The regimens were administered by oral gavage once daily for a period of three weeks. Animals were examined weekly for bodyweight, and the size of tumors was measured with calipers in 3 dimensions. All surgical procedures were performed under aseptic conditions. After 21 days, the mice were sacrificed, and the tumors were collected. Tumor volume and size was determined. The tumor volume was calculated using the following formula (Adeneye et al., 2010):

Tumor volume $\left(\mathrm{mm}^{3}\right)=(\mathrm{L} \times \mathrm{W} \times \mathrm{D}) \frac{1}{2}$.

Where,

$\mathrm{L}$ is the length (mm), $\mathrm{W}$ is the width ( $\mathrm{mm}$ ) and $\mathrm{D}$ is the depth of the tumor (mm).

\section{Results}

Determination of Marker Compounds by HPLC analysis

The identification of marker compounds in L. pumila extracts were determined by matching the retention time of the unknown peaks against standards eluted with same conditions as comparison. The standards, gallic acid (GA) and caffeic acid (CA) were resolved and eluted at $2.9 \mathrm{~min}$ and $4.6 \mathrm{~min}$, respectively. Both markers were present in the chromatographic profiles of both extracts and GA was found as the major peak in both extracts (Figure 1). Quantification analysis showed the amount of GA and CA were varied within the extract types. LPEW contained highest amount of GA (3.746 \pm 0.05$)$ and (CA, $0.194 \pm 0.05)$ while LPW showed lowest amount of GA and CA $(2.816 \pm 0.10$ and $0.062 \pm 0.12$ respectively) (Table 1). This suggest that, different types of extraction solvent used leads to different variations in the amount of constituents present. The present of these compounds might contribute to the activity in L. pumila. From this point onwards, GA and CA together with L. pumila

Asian Pacific Journal of Cancer Prevention, Vol 21 


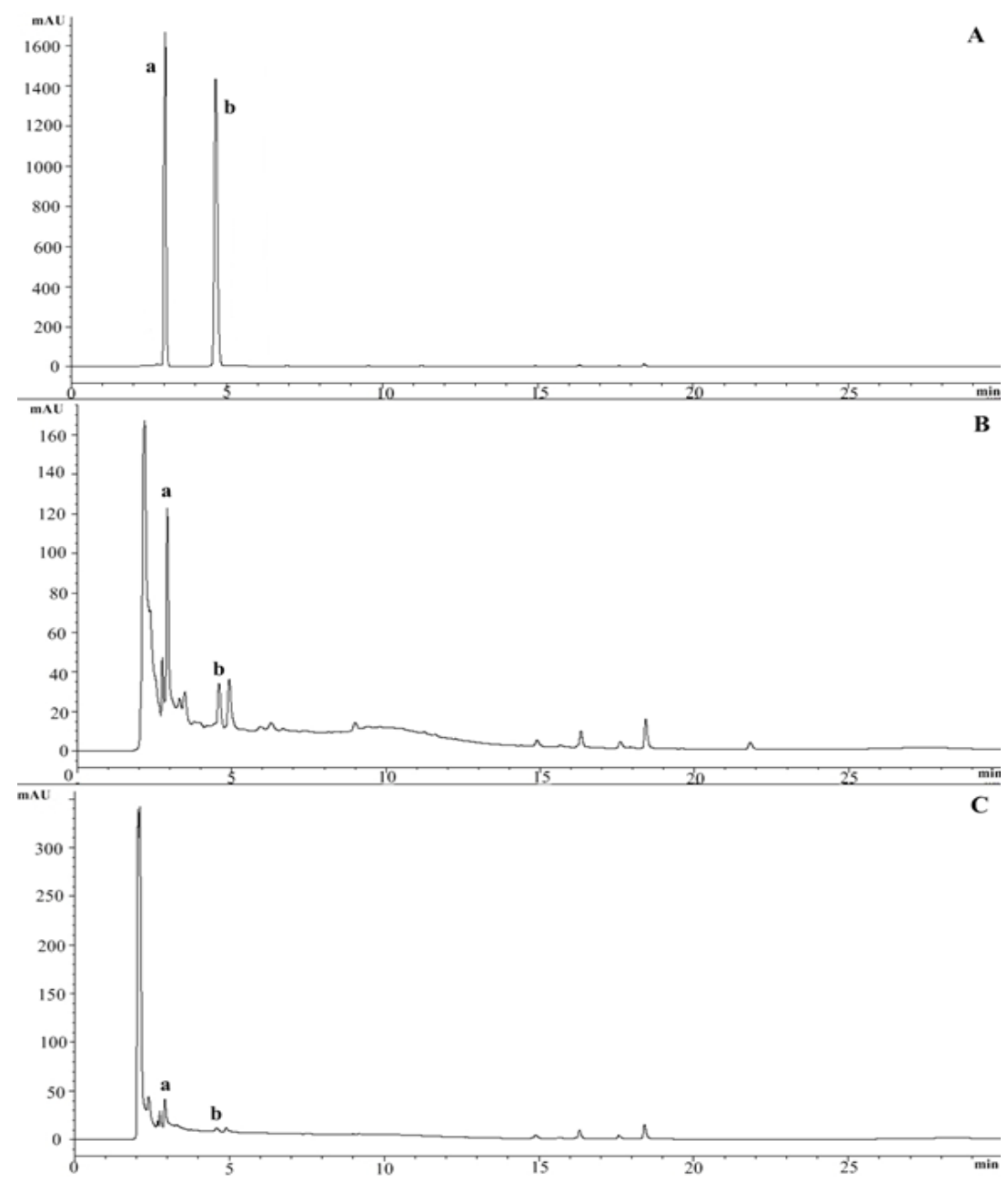

Figure 1. HPLC Chromatogram of L. pumila Extracts at $270 \mathrm{~nm}$ Performed under Gradient Conditions for 30 minutes. A), Standard mixture of chromatogram gallic acid and caffeic acid; B), Chromatogram of LPEW; C), Chromatogram LPW. a, Gallic acid; b, Caffeic acid. LPEW, L. pumila ethanol-water extract; LPW, L. pumila water extract

extracts, were used to further elucidate anti fibrosis potential involved in SK-UT-1 cells.

\section{Morphological changes in the SK-UT-1 cells treated with L. pumila extracts}

In the view of report by Zakaria et al., (2019) that revealed the cytotoxicity effect of $L$. pumila extracts against SK-UT-1 cells, we suspect that apoptosis as an underlying mechanism of SK-UT-1 cell death. In the first instance, we examined the morphological changes in response to the treatment under light contrast miscroscope. In untreated cell population, most of the cells were seen attached onto flask surface and displaying regular epithelial-like shape. In treated cell population most cells were dead and sloughed off, leaving an empty space behind. However, treatment at $\mathrm{IC}_{50}$ concentration (Zakaria et al., 2019) did not showed much differences between untreated and treated and for all treatments (LPEW, LPW, LPF, GA, CA and EGCG). On the other hand, treatment with $100 \mu \mathrm{g} / \mathrm{mL}$ and $250 \mu \mathrm{g} / \mathrm{mL}$, showed obvious morphological changes including cell shrinkage and membrane blebbing. Some were observed in spherical shape indicating the degree of loss of attachment and formation of apoptotic bodies. Analysis on morphological study was conducted using Acridine Orange/Propidium
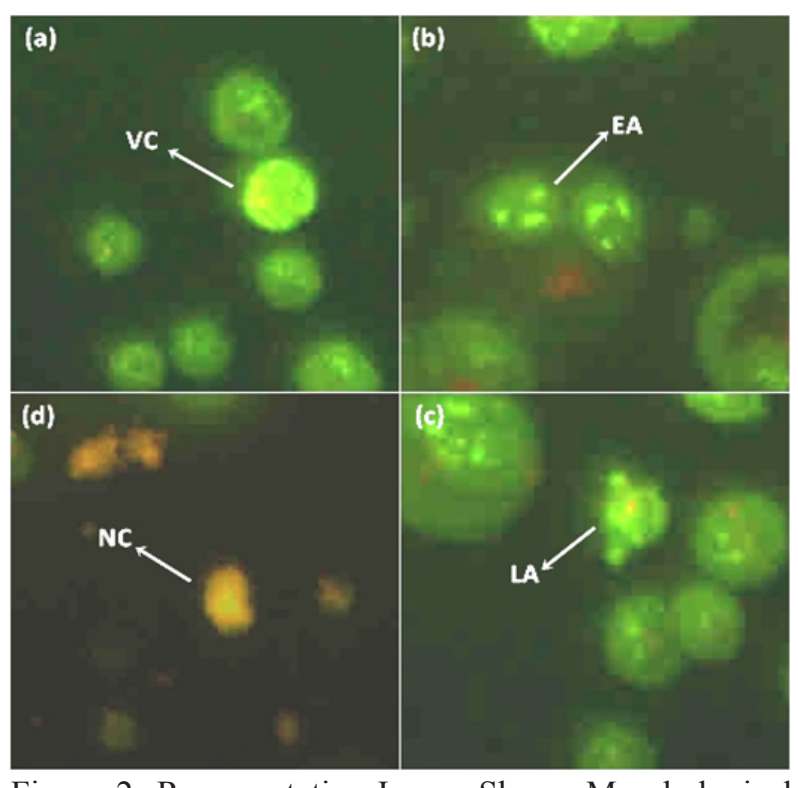

Figure 2. Representative Image Shows Morphological Observation of SKUT-1 Cells after Stainning with Acridine Orange-propidium Iodide (AO/PI) for 24h. (a) cells were untreated with L. pumila remain uniformly stained. (b), (c) and (d) were treated with L. pumila. Treated cells showed significant morphological changes and formation of apoptotic bodies.VC-viable cell; EA-early apoptotic; LA-late apoptotic; NC-necrosis. 
Table 1. Gallic acid and Caffeic acid Concentration in L. pumila Extracts. Result are depicted as average \% $\mathrm{w} / \mathrm{w} \pm \mathrm{SD}(\mathrm{n}=3)$. Significance level was expressed as $* * * \mathrm{p}<0.001$

\begin{tabular}{lcc}
\hline Extracts & Gallic acid $(\% \mathrm{w} / \mathrm{w})$ & Caffeic acid $(\% \mathrm{w} / \mathrm{w})$ \\
\hline LPEW & $3.746 \pm 0.05$ & $0.194 \pm 0.05$ \\
LPW & $2.816 \pm 0.10$ & $0.062 \pm 0.12$ \\
\hline
\end{tabular}

LPEW, L. pumila ethanol-water extract; LPW, L. pumila water extract

Iodide dual staining assay (AO/PI) and examined under flourescence microscope. Figure 2 showed the representative image of AO/PI staining for L. pumila extracts and its bioactive marker compounds treated on SK-UT-1 cells at different concentration. The untreated SK-UT-1 cells remained uniformly stained. The plasma membrane, nuclear envelope and nucleolus were complete. By contrast, the nuclei of SK-UT-1 cells treated with $L$. pumila exhibited condensed and fragmented chromatin, indicative of apoptosis. Result showed that L. pumila extracts and its bioactive marker compounds have the ability to induce apoptosis against SK-UT-1 cells.

Induction of apoptosis by L. pumila extracts and compounds against SK-UT-1 cells

To further confirm that L. pumila extracts and its bioactive compounds induces apoptosis, treated SK-UT-1 cells were stained with Annexin-V FITC/ PI and subsequently 10,000 cells were analyzed by flow cytometer. The analyzed cells were grouped into four quadrants based on the cell stage; viable cell, early apoptosis, late apoptosis and necrosis (Figure 3). The quadrant at the bottom on the left represents the viable cells which did not take both dyes. While cells at the early stage of apoptosis were stained with Annexin V due to high affinity to the externalized phosphatidylserine on the surface of plasma membrane which represented in the second quadrant at the bottom on the right. Cells that were in late apoptosis were stained with both dyes which represented in the third quadrant at top right and cells in necrosis were stained only with PI which represented in fourth quadrant at the top left. The proportion of SK-UT-1 cells in the early and late apoptotic and necrotic cell death modes were determined and presented in Figure 4. Treatment using $\mathrm{IC}_{50}$ concentration showed that the extracts significantly reduced $(\mathrm{p}<0.001)$ viable cell to $61.64 \%$. Approximately $25.64 \%$ of cells were in early apoptosis and $10.27 \%$ were in late apoptosis. In corroboration with morphological observation above, treatment with higher concentration $(100 \mu \mathrm{g} / \mathrm{mL})$ of extracts showed significant decreased $(p<0.001)$ of viable cell population as well as increased the number of cells undergoing apoptosis in all treatments. Meanwhile treatment at $250 \mathrm{ug} / \mathrm{mL}$ concentration caused a significant increased in late apoptosis event in all treatments. These results indicate at $50 \%$ inhibition concentration, there were minimal effect on apoptosis induction by the extracts and the markers. However, at higher concentration, the growth inhibition by the extracts and marker compounds

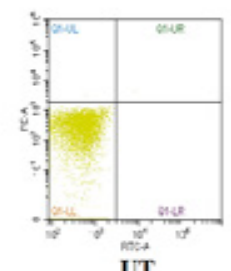

a)

IC so values $(\mu \mathrm{g} / \mathrm{mL})$

b)

$100 \mu \mathrm{g} / \mathrm{mL}$

c)

$250 \mu \mathrm{g} / \mathrm{mL}$
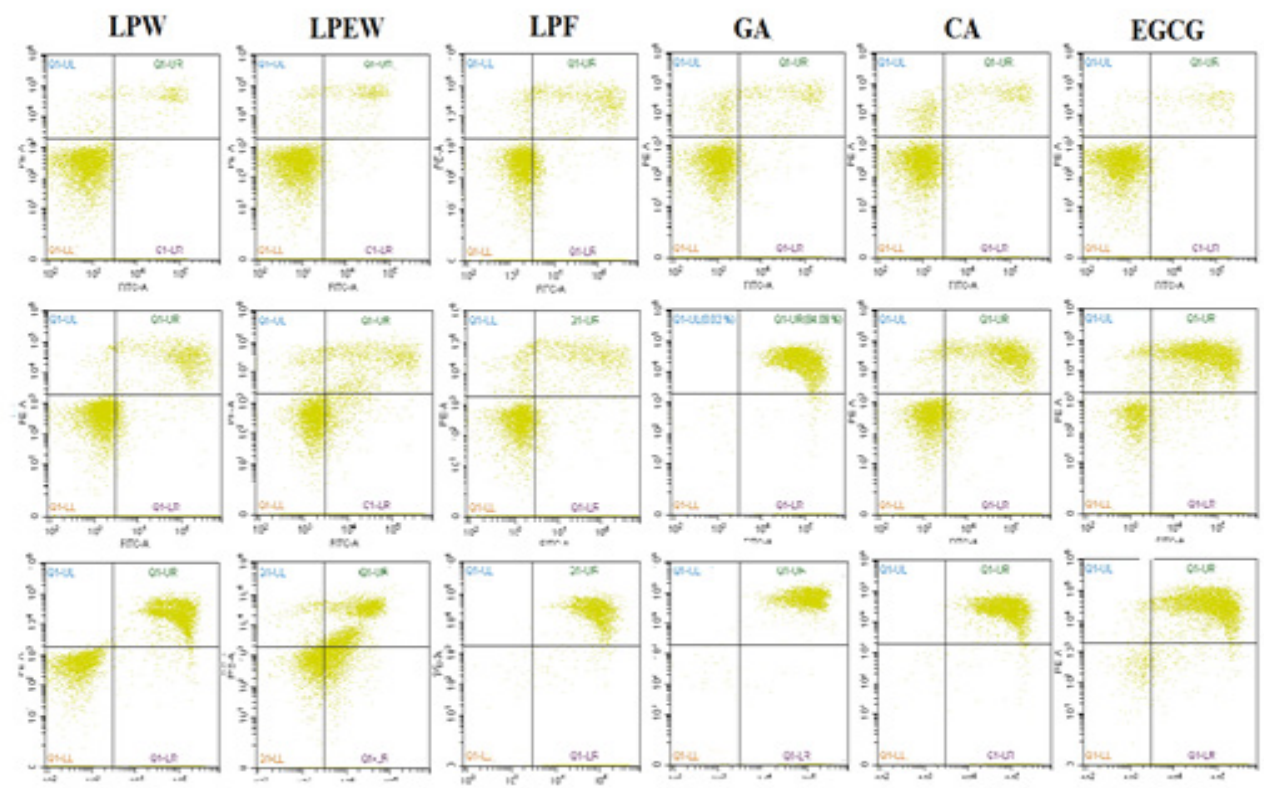
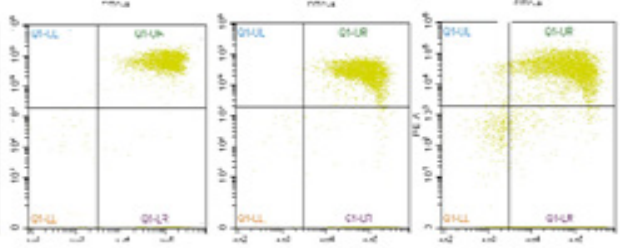

Figure 3. Scatter Plots of Annexin V-FITC/PI dual Staining Induction of Apoptosis of L. pumila Extracts and Its Bioactive Marker Compounds for $24 \mathrm{~h}$ According to their (a) Treatment Based on $\mathrm{IC}_{50}$ Values (LPW, $28 \mu \mathrm{g} / \mathrm{mL}$; LPEW, $22 \mu \mathrm{g} / \mathrm{mL}$; LPF, 32 $\mu \mathrm{g} / \mathrm{mL}$; GA, $4 \mu \mathrm{g} / \mathrm{mL}$; CA, $8 \mu \mathrm{g} / \mathrm{mL}$; and EGCG, $22 \mu \mathrm{g} / \mathrm{mL}$ ) (b) SK-UT-1 Cells Treated with $100 \mu \mathrm{g} / \mathrm{mL}$, (c) SK-UT-1 Cells Treated with $250 \mu \mathrm{g} / \mathrm{mL}$. 
a)

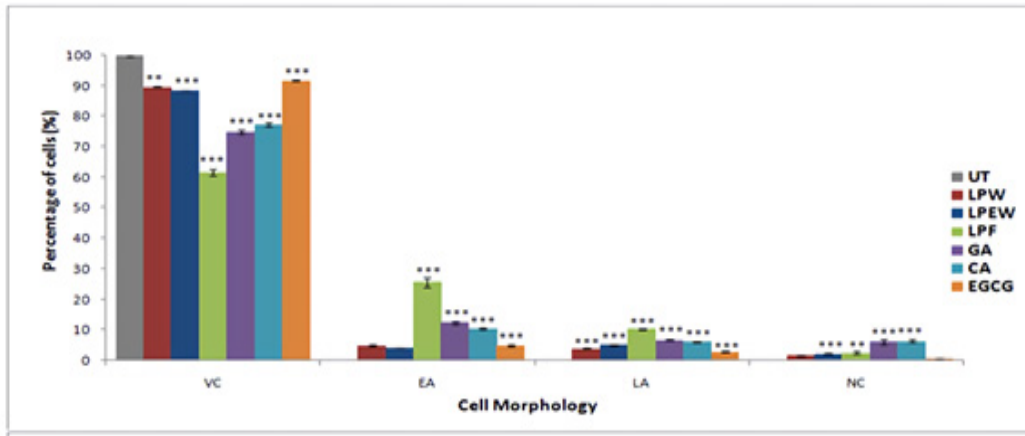

b)

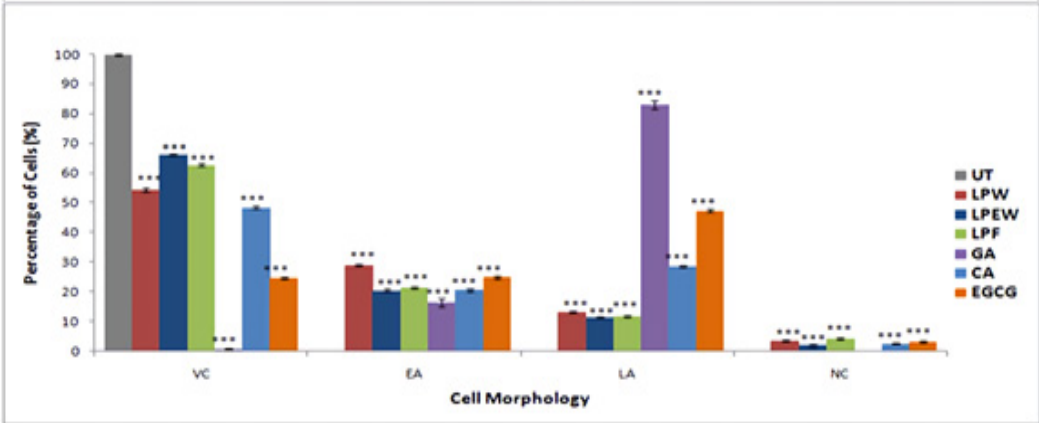

c)

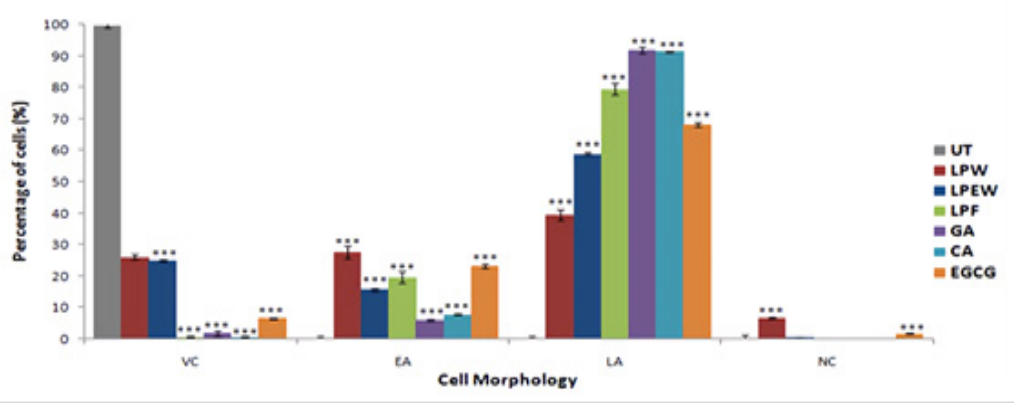

Figure 4. The Percentage of Viable, Apoptosis and Necrosis in SK-UT-1 Cells after Treatment with L. pumila Extracts and Its Biomarker Using Annexin V-FITC/PI Flow Cytometry Quantification. Data were expressed by mean \pm SD, $(n=3)$. One way ANOVA was used for statistical analysis and the significant differences from untreated control are indicated by $* \mathrm{p}<0.05, * * \mathrm{p}<0.01$ and $* * * \mathrm{p}<0.001$. (a) Treatment based on $\mathrm{IC}_{60}$ values (LPW, $28 \mu \mathrm{g} / \mathrm{mL} ; \mathrm{LPEW}, 22$ $\mu \mathrm{g} / \mathrm{mL}$; LPF, 32 $\mu \mathrm{g} / \mathrm{mL}$; GA, $4 \mu \mathrm{g} / \mathrm{mL}$; CA, $8 \mu \mathrm{g} / \mathrm{mL}$; and EGCG, $22 \mu \mathrm{g} / \mathrm{mL})$ (b) 100 ( $\mu \mathrm{g} / \mathrm{mL})$ (c) 250 ( $\mu \mathrm{g} / \mathrm{mL})$. UT, untreated; LPW, L. pumila water extract; LPEW, L. pumila ethanol-water extract; LPF, L. pumila formulation; GA, gallic acid; CA, caffeic acid; EGCG, epigallocatechin gallate.

was mainly due to the induction of apoptotic cell death in SK-UT-1 cell lines.

In vivo uterine fibroid xenograft in athymic mouse model

To evaluate the anti-tumor effect of L. pumila extracts, SK-UT-1 cells were injected subcutaneously into the right flank of the nude mice. The mice were treated with formulated extract of L. pumila, LPF. LPF exhibited high significant anti-uterine fibroid activity on 21 st post cell inoculation day. Figure 5(i) shows the average tumor volume in which the two doses of LPF (200 and $400 \mathrm{mg} / \mathrm{kg}$ ) reduced tumor volume significantly compared to control group ( $\mathrm{p}<0.001)$. Percentage reduction in tumor volume for the different groups shown in Figure 5(ii). Figure 5(iii) shows tumor size for each group after treatment. The treatment with LPF at concentration of 200 and $400 \mathrm{mg} / \mathrm{kg}$ showed reduction of the tumor volume of 48.34 and $53.97 \%$, respectively. The body weight for the mice from each group was recorded weekly throughout the experiment, no significant reduction of body weight were observed, Figure 5(iv).

\section{Discussion}

Studies have shown that ethanol extract of L. pumila and its active fraction possess antiproliferative and proapoptotic effect in various cell lines while having reduced effects on non-malignant cells. In present study, we reported that $L$. pumila moderately induced apoptotic cell death against SK-UT-1 in concentration dependent manner. Our HPLC analysis indicate that bioactive markers, caffeic acid and gallic acid are present in the extracts tested. Cumulating evidence has revealed that both compounds may serve as potential adjunct to chemotherapy in cancer treatment. Gallic acid has been shown to have cytotoxic effects in certain cancer cells, without damaging normal cells. Faried et al. (2007) indicated that gallic acid isolated from Phaleria macrocarpa induced cancer cell death in various cancer cells such as breast cancer (MCF-7), gastric cancer (MKN-28) and colon cancer (HT-29, colon 201 and colon 26). Gallic acid also showed a pro-apoptotic activity mediated, at least in part, by the production of $\mathrm{H}_{2} \mathrm{O}_{2}$ in leukemia cancer cells (Fabiani et al., 2011). 

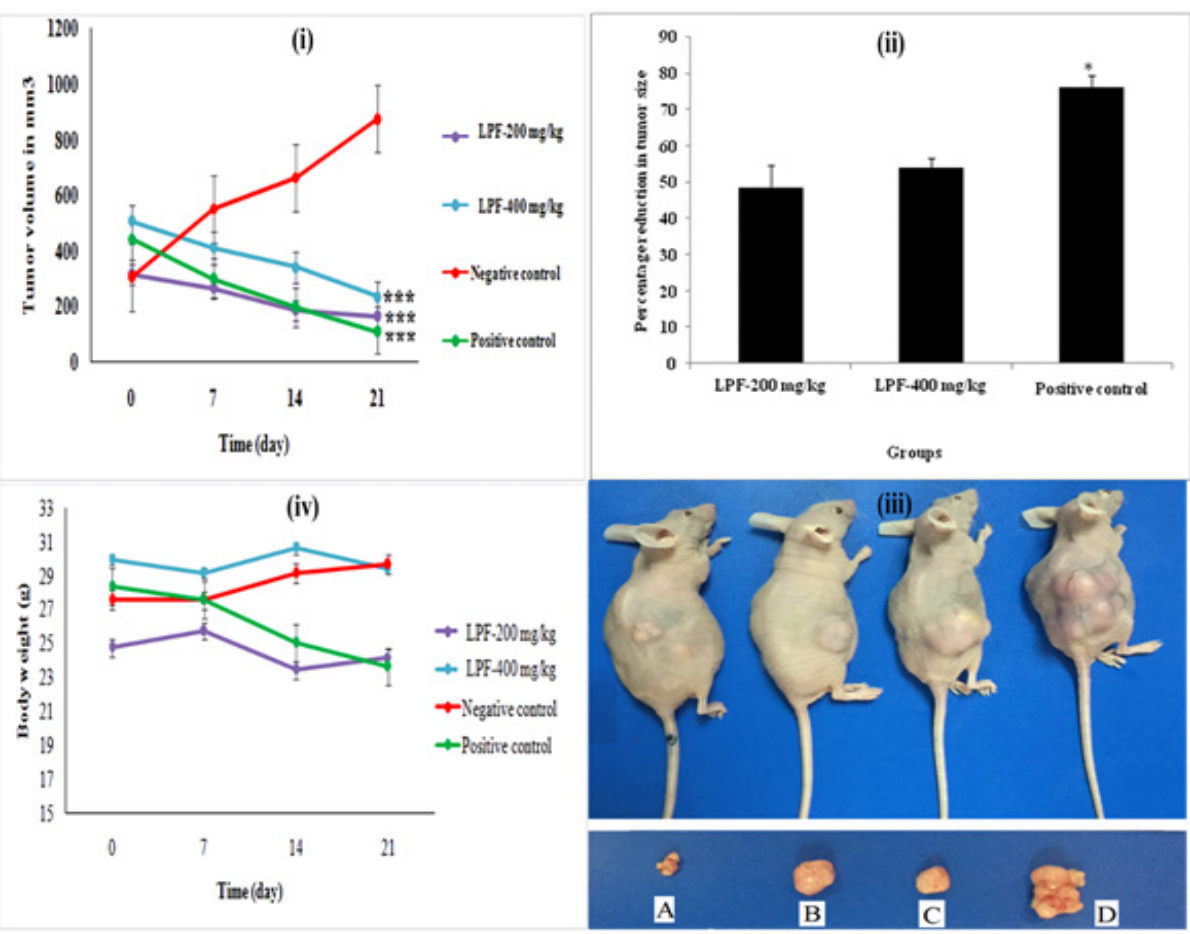

Figure 5. (i) Tumor Volume of the Uterine Fibroid Induced Mice Treated with LPF-200 mg/kg, LPF-400 mg/kg, Negative Control and Positive Control. The data indicated high significant reduction in tumor size compared to negative control group. $* \mathrm{P}<0.05, * * \mathrm{P}<0.01, * * * \mathrm{P}<0.001$. (ii) Percentage reduction in the uterine fibroid tumor size for LPF$200 \mathrm{mg} / \mathrm{kg}, \mathrm{LPF}-400 \mathrm{mg} / \mathrm{kg}$ and positive control. The data indicated high reduction in tumor size. The positive control group indicated significant reduction in tumor size as compared to LPF-200 mg/kg and LPF-400 mg/kg, respectively. $* \mathrm{P}<0.05, * * \mathrm{P}<0.01, * * * \mathrm{P}<0.001$. (iii) Photos show representative mice with tumors from each group after treatment. A, LPF-400 mg/kg; B, LPF-200 mg/kg; C, positive control and D, negative control. (iv) Body weight for LPF-200 mg/ $\mathrm{kg}, \mathrm{LPF}-400 \mathrm{mg} / \mathrm{kg}$, negative control and positive control for 21 days.

Morphological assessment and flow cytometry analysis were conducted to understand the morphological assessment and mode of cell death of the extracts and its bioactive compounds. Both analysis suggest that the growth inhibition by L. pumila extracts was mainly due to induction apoptotic cell death. In animal study, it clearly shown that $L$. pumila extract significantly reduced tumor size in tested mice. This result indicated that the extract of L. pumila was able to suppress tumor growth even though it only have moderate apoptotic effects.

One of the biggest challenges for the use of herbal bioactives is their poor solubility and bioavailability. These limitations could be resolved by reducing the size of the bioactive to enhance the solubility and increasing the bioavailability thereof (Medina et al., 2004; Angare et al., 2012; Agrawal et al., 2012). Recently, many researchers have utilized the nanomedicines for the delivery of plant bioactives or herbal extracts. Nanosystems can distribute the bioactive component at adequate concentration throughout the whole treatment period, directing it to the preferred site of action. In the present study, liposome of L. pumila showed in vivo anti-uterine fibroid effects by significant reduction of the tumor size. It is found that the phytoconstituents presents in L. pumila, such as gallic acid and caffeic acid have been shown to be the bioactive compounds with remarkable inhibitory effects the proliferation of cancer cells and to inhibits angiogenesis (Chang et al., 2010; Zhao and Hu, 2013; Lu et al., 2010). A number of nanodosage forms can be developed like, liposomes, solid lipid nanoparticles, nanoemulsion, nanocapsules and phytosomes. Among these, liposome has the capability to makes it more preferable delivery system for these herbal bioactives, like its biocompatibility, drug loading efficiency for hydrophilic, lipophilic and amphiphilic compounds and acted by changing the bilayer chemical composition which may regulate the pharmacokinetic properties of a drug (Liu et al., 2014; Lin and Gu, 2014; Martins et al., 2011). In this study, L. pumila liposome was developed and showed its effectiveness in in vivo mechanism by reducing the tumor development. Thereby, nanoformulation of plant extracts could be a valuable aid in increased the efficiency of plant extract and minimise their side effects.

In vitro study anti-uterine fibroid activity showed that L. pumila induced apoptosis in a dose dependent manner. Anti tumor evaluation through xenograft model shows that L. pumila formulation significantly inhibits the ectopic implanted uterine fibroid tumor in immune-compromised mouse xenograft model. In cancer treatment, one of the approaches to restrain tumor growth is by activating the apoptotic machinery in the tumor cells (Call et al., 2008; Gerl and Vaux, 2005). Cell proliferation and apoptotic cell death are important determinants of growth of a tumors (Lowe and Lin, 2000). As many chemotherapeutic agents have been identified to be able to induce apoptosis in cancer cells, (Liu et al., 2000; Hannun, 1997; Simstein et al., 2003) apoptosis has been considered as a method for the treatment of cancer. Our finding indicated that, L. pumila was able to shrink the uterine fibroid cancerous cell. Therefore, the mechanisms underlying this 
potential were suggested due to the cumulative effect of phytoconstituents particularly, gallic acid and caffeic acid found in L. pumila extracts. The presence of both active compounds in L. pumila inhibit the cell viability and proliferation activities and thus promoted induction of apoptosis on SK-UT-1 cells.

To our knowledge, this is the first study that addresses the potential effect of $L$. pumila extracts on uterine fibroid cancer. Currently, L. pumila is widely consume by local people and various research have been made that suggested the plant extract can improve the well-being of women and posseses an anticancer effects. Therefore, as an important plant in traditional malay medicine and the potential of this plant possesses, L. pumila were utilized for the treatment of uterine fibroids. Based on the data, we suggest that $L$. pumila extracts and it bioactive markers play a significant role in treatment of uterine fibroids. Further evaluation of L. pumila extract in well-designed clinical trials in women with uterine fibroid tumors is warranted.

\section{Acknowledgements}

Authors are very grateful School of Pharmaceutical Sciences, Universiti Sains Malaysia (USM) for granting the permission to carry out the chemical profiling and quality control analysis of L. pumila var alata, and Eman Biodiscoveries laboratoriy, EUREKA Complex, Universiti Sains Malaysia (USM), Penang, Malaysia for in vivo uterine fibroid study.

\section{References}

Adeneye A, Adeyemi O, Agbaje E. (2010). Anti-obesity and antihyperlipidaemic effect of Hunteria umbellata seed extract in experimental hyperlipidaemia. J Ethnopharmacol, 130, 307-14.

Agrawal S, Giri TK, Tripathi DK, Ajazuddin, Alexander A (2012). A Review on novel therapeutic strategies for the enhancement of solubility for hydrophobic drugs through lipid and surfactant based self micro emulsifying drug delivery system: a novel approach. Am J Drug Discov Dev, 2, 143-83.

Ahamed MBK, Aisha AF, Nassar ZD, et al (2012). Cat's whiskers tea (Orthosiphon stamineus) extract inhibits growth of colon tumor in nude mice and angiogenesis in endothelial cells via suppressing VEGFR phosphorylation. Nutr Cancer, 64, 89-99.

Aisha AF, Majid AMSA, Ismail Z (2014). Preparation and characterization of nano liposomes of Orthosiphon stamineus ethanolic extract in soybean phospholipids. BMC Biotechnol, 14, 23.

Al-Suede FSR, Farsi E, Ahamed MKB, Ismail Z, Majid ASA. (2014). Marked antitumor activity of cat's whiskers tea (Orthosiphon stamineus) extract in orthotopic model of human colon tumor in nude mice. J Biochem Technol, $\mathbf{3}$, 170-6.

Angare D, Giri T, Tripathi DK, Alexander A, Ajazuddin (2012). Unexplored areas and new findings in lipid emulsion serving as a potential drug carrier for lipophilic drugs: a review. Trend Med Res, 7, 1-24.

Azimahtol HLP, Zainul AZ, Fezah O (2012). Antiproliferative and proapoptotic effects of Labisia pumila ethanol extract and its active fraction in human melanoma
HM3KO cells. Evid Based Complement Alternat Med, doi: $10.1155 / 2012 / 123470$.

Burkill IH (1966). A dictionary of the economic products of the Malay Peninsula, 2nd edition. Kuala Lumpur: Government of Malaysia and Singapore Publication.

Buttram VJ, Reiter RC (1981). Uterine leiomyomata: etiology, symptomatology, and management. Fertil Steril, 36, 433-5.

Call JA, Eckhardt SG, Camidge DR. (2008). Targeted manipulation of apoptosis in cancer treatment. Lancet Oncol, 9, 1002-11

Chang HS, Lin YJ, Lee SJ, et al (2009). Cytotoxic alkyl benzoquinones and alkyl phenols from Ardisia virens. Phytochemistry, 70, 2064-71.

Chang W, Hsieh C, Hsiao M, et al (2010). Caffeic acid induces apoptosis in human cervical cancer cells through the mitochondrial pathway. Taiwan J Obstet Gynaecol, 49, 419-24.

Chua LS, Abdul N, Lee SY, et al., (2011). Flavonoids and phenolic acids from Labisia pumila (Kacip Fatimah). Food Chem, 127, 1186-92.

Fabiani R, Rosignoli P, De-Bartolomeo A, et al (2011). The production of hydrogen peroxide is not a common mechanism by which olive oil phenols induce apoptosis on HL60 cells. Food Chem, 125, 1249-55.

Faried A, Kurnia D, Faried L, et al (2007). Anticancer effects of gallic acid isolated from indonesian herbal medicine, Phaleria macrocarpa (Scheff) Boerl, on human cancer cell lines. Int J Oncol, 30, 605-13.

Farquhar CM, Steiner CA (2002). Hysterectomy rates in the United States 1990-1997. Obstet Gynecol, 99, 229-34.

Gerl R, Vaux DL (2005). Apoptosis in the development and treatment of cancer. Carcinogenesis, 26, 263-70.

Ghafar G, Aisha AFA, Beh HK, Hamil SR (2013). In the open conference proceeding of ICNP. Standardization and Preliminary Anti-Angiogenic Study of Labisia pumila, 1(3335).

Hannun YA (1997). Apoptosis and the dilemma of cancer chemotherapy. Blood, 89, 1845-53.

Ibrahim J, Young-Hwa K, Dae-Yeon S, Byung HH (1996). Inhibitory effects of Malaysian medicinal plants on the platlet-activating factor (PAF) receptor binding. Nat Prod Sci, 2, 86-9.

Karimi E, Jaafar HZE, Ahmad S (2011). Phytochemical analysis and antimicrobial activities of methanolic extracts of leaf, stem and root from different varieties of Labisa pumila benth. Molecules, 16, 4438-50.

Kobayashi H, De Meji'a E (2005). The genus Ardisia: A novel source of health promoting compounds and phytopharmaceuticals. J Ethnopharmacol, 96, 347-54.

Lethaby A, Vollenhoven B, Sowter M (2002). Efficacy of pre-operative gonadotrophin hormone releasing analogues for women with uterine fibroids undergoing hysterectomy or myomectomy: A systematic review. BJOG, 109, 1097-1108.

Lin X, Gu N (2014). Surface properties of encapsulating hydrophobic nanoparticles regulate the main phase transition temperature of lipid bilayers: a simulation study. Nano Res, 7, 1195-204.

Liu J, Shen HM, Ong CN (2000). Salvia miltiorrhiza inhibits cell growth and induces apoptosis in human hepatoma HepG2 cells. Cancer Lett, 153, 85-93.

Liu Y, Yin J-J, Nie Z (2014). Harnessing the collective properties of nanoparticle ensembles for cancer theranostics. Nano Res, 6, 1-12

Lowe SW, Lin AW (2000). Apoptosis in cancer. Carcinogenesis, 21, 485-95.

Lu Y, Jiang H, Wu K, et al (2010). Gallic acid suppresses cell vaibility, proliferation, invasiona and angiogenesis in human 
glioma cells. Eur J Pharm, 641, 102-7.

Malik A, Mendoza M, Payson M, Catherino WH (2009). Curcumin, a nutritional supplement with antineoplastic activity, enhances leiomyoma cell apoptosis and decreases fibronectin expression. Fertil Steril, 91, 2177-84.

Manneras L, Fazliana M, Wan Nazaimoon WM, et al (2010). Beneficial metabolic effects of the Malaysian herb Labisia pumila var. alata in a rat model of polycystic ovary syndrome. J Ethnopharmacol, 127, 346-51.

Martins GV, Mano JOF, Alves NLM (2011). Dual responsive nanostructured surfaces for biomedical applications. Langmuir, 27, 8415-23.

Medina OP, Zhu Y, Kairemo K (2004). Targeted liposomal drug delivery in cancer. Curr Pharm Des, 10, 2981-9.

Melissa PSW, Navaratnam V, Yin CY (2013). Estrogenic assessment of Labisia pumila extracts using a human endometrial cell line. Int J Pharm Pharm Sci, 5, 448-52.

Mohamad N, Mahmood M, Mansor H (2009). Antioxidative properties of leaf extracts of a popular Malaysian herb, Labisia pumila. J Med Plant Res, 3, 217-23.

Nadia ME, Nazrun AS, Norazlina M, et al (2012). The anti-inflammatory, phytoestrogenic, and antioxidative role of labisia pumila in prevention of postmenopausal osteoporosis. Adv Pharmacol Sci, https://doi.org/10.1155/2012/706905.

Rasadah MA, Nik-Musa'adah M, Aznie-Aida A, Mohd.-Rizal AK (2001). Inhibitory activity of some selected Malaysian medicinal plants on TPA induced mouse ear oedema. In: Ahmad Sazali et al. (Eds.), Fine Chemicals from Natural Resources. University Publication Centre, University of Technology MARA, Shah Alam, Malaysia, pp 371-6.

Saeed MAA (2018). Isolation and identification of chemical markers from labisia pumila (Blume) and preparation of standardized and nanoformulated extracts for anti-iobesity, anti-uterine fibroid and anti-cervical cancer studies. (Doctoral dissertation). University of Sains, Malaysia.

Sankaran S, Manyonda IT (2008). Medical management of fibroids. Best Pract Res Clin Obstet Gynaecol, 22, 655-76.

Simstein R, Burow M, Parker A, Weldon C, Beckman B (2003). Apoptosis, chemoresistance, and breast cancer: insights from the MCF-7 cell model system. Exp Biol Med, 228, 995-1003

Stewart EA (2001). Uterine fibroids. Lancet, 357, 293-8.

Stone BC (1988). Notes on the Genus Labisia Lindl (Myrsinaceae). Malay Nat J, 42, 43-51.

Surh YJ (2003). Cancer chemoprevention with dietary phytochemicals. Nat Rev Cancer, 3, 768-80.

Tajudin TJSA, Mat N, Siti-Aishah AB, et al (2012). Cytotoxicity, antiproliferative effects, and apoptosis induction of methanolic extract of cynometra cauliflora linn. Whole fruit on human promyelocytic leukemia HL-60 cells. Evid Based Complement Alternat Med, https://doi.org/ $10.1155 / 2012 / 127373$.

Vidya PR, Nagini S (2012). Cancer chemoprevention by dietary phytochemicals: promises and pitfalls. Curr Pharm Biotechnol, 13, 125-36.

Walker CL, Stewart EA (2005). Uterine fibroids: The elephant in the room. Science, 308, 1589-92.

Zakaria M, Mustafa AM (2010). Traditional Malay medicine plants. Kuala Lumpur; Fajar bakti Sdn Bhd.

Zakaria N, Saeed MAA, Ismail Z, Mohd KS (2019). Standardization and cytotoxicity analysis of Labisia pumila var alata for anti-uterine fibroid. Biosci Res, 16, xx. In press

Zhang D, Al-Hendy M, Richard-Davis G, et al (2010). Green tea extract inhibits proliferation of uterine leiomyoma cells in vitro and in nude mice. Am J Obstet Gynecol, 202, 289-e1.

Zhao B, Hu M (2013). Gallic acid reduces cell viability, proliferation, invasion and angiogenesis in human cervical cancers cells. Oncol Lett, 6, 1749-55.
Zhari I, Norhayati I, Jaafar L (1999). Malaysian herbal monograph. Volume 1. Kuala Lumpur: Malaysian Monograph Committee (Kementerian Kesihatan Malaysia).

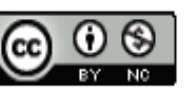

This work is licensed under a Creative Commons AttributionNon Commercial 4.0 International License. 